\title{
Marital Satisfaction of Couples with Behcet and Familial Mediterranean Fever
}

\section{Behçet ve Ailevi Akdeniz Ateşi Hastaliği Olan Çiftlerde Evlilik Doyumu}

\author{
Merve Deniz Pak ${ }^{l}$, Veli Duyan ${ }^{* 2}$
}

\begin{abstract}
Aim/Background: Marital satisfaction can be defined as the attitude an individual has toward his or her own marital relationship. Crises may affect marital satisfaction and one of the factors causing the crisis is diseases. The aim of the study is to examine the marital satisfaction of couples with Behcet and Familial Mediterranean Fever. Method: The research is a cross-sectional field study in the screening model. Participants consisted of 68 couples diagnosed with Behcet and Family Mediterranean Fever Disease. Golombok-Rust Marriage Status Inventory was used with the questionnaire to collect data. In the first part of the questionnaire, the sociodemographic characteristics and the information about the disease were asked. In the second part, there are 13 questions that can be answered in a triple Likert type to determine the changes in family and social relationships after the diagnosis. Data were obtained between February 1, 2017 and June 1, 2017 and analyzed via SPSS 22. Results: All of the participants were married with official marriage, $69.1 \%(n=94)$ were willingly married and $89.7 \%(n=61)$ had children. $33.1 \%$ of the participants have Family Mediterranean Fever and $16.9 \%$ have Behcet Disease. With the diseases; $13.2 \%$ of the participants $(n=18)$ were less likely to share important issues with family members, $12.5 \%(\mathrm{n}=17)$ who reported degrading behavior to family members, $17.6 \%$ reported that family members were less likely to support each other, $18.4 \%(\mathrm{n}=25)$ stated that the displeasure among the family members increased. $13.2 \%$ said that they share less important issues with their family members, $12.5 \%$ have a negative attitude towards family members, and $17.6 \%$ said that family members have less support, $18.4 \%$ of the family members increased their frustration and $59.6 \%$ of them had a lower frequency of sexual intercourse. Participants in the inventory scores, $4.4 \%$ were undefined, $14 \%$ were very good and $11 \%$ were good; $6.6 \%$ were above average, $20.6 \%$ were mediocre and $8.1 \%$ were in weak point range. Conclusion: Behcet and Family Mediterranean Fever diseases affect marital satisfaction and it is recommended that families with these diseases may have family counseling, psychoeducation and sexual counseling services.
\end{abstract}

Key words: Family counseling, marriage satisfaction, Behcet Disease, Family Mediterranean Fever

ÖZET

Giriş: Evlilik doyumu, bireyin evlilik ilişkisindeki gereksinimlerini, taleplerini karşılama derecesine yönelik algısıdır. Evlilik ilişkisinde yaşanan krizler doyumu etkilemektedir. Kriz yaratabilen faktörlerden biri de hastalıklardır. Bu doğrultuda çalışmanın amacı, Behçet ile Ailevi Akdeniz Ateşi hastası olan çiftlerin evlilik doyumunun irdelenmesidir. Yöntem: Araştırma, tarama modelinde kesitsel bir saha çalışmasıdır. Araştırmanın çalışma grubunu, Behçet ve Ailevi Akdeniz Ateşi hastalığı tanısı alan 68 çift oluşturmuştur. Veri toplamak amacıyla soru kâğıdı ile Golombok-Rust Evlilik Durumu Envanteri kullanılmıştır. Soru kâğıdının birinci bölümünde, sosyo-demografik özelliklere ve hastalığa dair bilgiler sorulmuştur. İkinci bölümdeyse, hastalık sonrasında aile ilişkileri ve sosyal çevreyle ilişkilerin değişimini belirlemek için üçlü Likert tipinde yanttlanabilecek 13 soru bulunmaktadır. Çalışmada veriler, 1 Şubat 2017- 1 Haziran 2017 tarihleri arasında elde edilmiş ve SPSS programında analiz edilmiştir. Bulgular: Araştırma bulgularına göre, katılımcıların tümü resmi nikâhla evli olup, \%69,1'inin isteyerek evlendiği ve \%89,7'sinin çocuğunun olduğu belirlenmiştir. Katılımcıların \%33,1'i Ailevi Akdeniz Ateşi Hastalığı, \%16,9’u Behçet Hastasıdır. \%13,2'si hastalık sonrası aile üyeleriyle önemli konuları paylaşmanın azaldığını, \%12,5'i aile üyelerine küçük düşürücü söz söyleme davranışlarının arttığını, \%17,6'sı aile üyelerinin birbirlerine desteğinin azaldığını, \%18,4'ü aile üyeleri arasında kırgınlığın arttığını ve \%59,6'sı cinsel ilişki sıklığının azaldığını ifade etmiştir. Ölçek puanlamasında, katılımcıların \%4,4'ü tanımsız, \% 14'ü çok iyi ve \%11'i iyi, \%6,6'sı vasat üstü, \%20,6'sı vasat ve \%8,1'i zayıf puan aralığında yer almıştır. Sonuç: Sonuç olarak, Behçet ve Ailevi Akdeniz Ateşi hastalığı evlilik doyumu üzerinde etki yaratmaktadır ve bu hastalığı olan çiftlere aile danışmanlığı, psikoeğitim ve cinsel danışmanlık hizmetlerinden faydalanmaları önerilebilir.

Anahtar kelimeler: Aile danışmanlığı, evlilik doyumu, Behçet Hastalığı, Ailevi Akdeniz Ateşi Hastalığı

Received Date / Geliş tarihi: 29.03.2018, Accepted Date / Kabul tarihi: 28.05.2018

${ }^{1}$ Başkent Üniversitesi Sağlık Bilimleri Fakültesi Sosyal Hizmet Bölümü, Ankara, TÜRKIYE.

${ }^{2}$ Ankara Üniversitesi Sağlık Bilimleri Fakültesi Sosyal Hizmet Bölümü, Ankara, TÜRKIYE.

*Address for Correspondence / Yazışma Adresi: Veli Duyan, Ankara Üniversitesi Sağlık Bilimleri Fakültesi Sosyal Hizmet

Bölümü Ankara, TÜRKIYE.

E-mail: vduyan@health.ankara.edu.tr

Pak MD, Duyan V. Behçet ve Ailevi Akdeniz Ateşi Hastaliği Olan Çiftlerde Evlilik Doyumu. TJFMPC, 2018;12(4): 239-249.

DOI: $10.21763 /$ tjfmpc.465765 


\section{GíRIŞ}

Evlilik, insanlığın var oluşundan beri çeşitli ihtiyaçların karşılanmasına yönelik kurulmuş bir bağdır. Fiziksel yönden cinsel güdüyü doyurmak; sosyal olarak ait olma, güven duyma, koruma ve korunma, dayanışma; duygusal olarak sevme-sevilme; ekonomik olarak geçim zorluğuna beraber katlanma gibi evliliğin pek çok güçlüğün üstesinden gelmede işlevinin olduğu görülmektedir. ${ }^{1}$ Evlilik ilişkisi içerisinde gereksinimlerin karşılanması, gündeme "evlilik doyumu" konusunu getirmektedir. Evlilik doyumu, en basit ifadeyle "bireyin kendi evlilik ilişkisindeki gereksinimlerini karşılama derecesine ilişkin algısı" olarak tanımlanabilir. ${ }^{2}$ Evlilik doyumu, içsel ve dişsal pek çok faktörden etkilenebilir. Evlilik ilişkisinde, kriz yaratabilen ve evlilik doyumunu etkileyenbilen bu faktörlerden en önemlilerinden biri hastalıklardır. Hastalıklar, ailenin yaşam döngüsünde krize neden olarak evlilik doyumunu etkileme potansiyeline sahiptir. Hastalık halinde, aile bireylerinin enerjilerini hastalığa ve tedaviye yöneltmesi ilişkilerdeki dengeyi bozma riskini beraberinde getirir. Özellikle tedavisi mümkün olmayan, tamamen iyileşmeyen veya ataklarla seyreden kronik hastalıklarda bu risk artmaktadır. Literatürde yapılan çalışmalar incelendiğinde, depresyon, diyabet, kanser, yeme bozuklukları ve romatoid artrid gibi hastalıkların evlilik doyumunda olumsuz etki yarattığ görülmektedir. ${ }^{3,4,5}$ Dünya çapında, en sık Türkiye'de rastlanan kronik hastalıklardan Behçet ve Ailevi Akdeniz Ateşi Hastalığı (FMF) da, genellikle bireylerin üreme fonksiyonlarının üst düzeyde olduğu yetişkinlik döneminde görülür. Bu hastalıklar, romatolojik tipte, nadir görülen ve kalıcı tedavileri bulunmayan hastalıklardır. $\mathrm{Bu}$ yönleriyle, bu hastalıkların evlilik ilişkisini olumsuz etkileme potansiyeline sahip olduğu düşünülmektedir.

Yasal, toplumsal ve ekonomik bir kurum olan aile; biyolojik, psikolojik ve sosyal ilişkilerle bağlı olan ve duygusal etkileşimlerin olduğu açık bir sistemdir. Bu sisteme, Behçet ve FMF hastalıkları gibi kronik ve tedavisi mümkün olmayan hastalıkların girişi, ilişkilerde işlevselliği sağlıklı devam ettiremeye yönelik yeni bir yapı oluşturulup denge halinin yeniden sağlanmasını gerektirmektedir. Fakat literatüre bakıldığında, bu hastalıkları evlilik ilişkisi çerçevesinde ele alan çalışmaların olmadığı; Behçet ve FMF hastalarının evlilik doyum düzeylerinin bilinmediği ve buna yönelik gereksinimlerin ortaya konulmadığı görülmektedir. Buradan hareketle bu çalışmanın amacı, Behçet ve FMF hastalarının evlilik doyum düzeylerinin belirlenmesi ve sonucunda gereksinimlerinin ortaya konulmasidır.

\section{Evlilik Doyumu Kavramına Genel Bakış}

Evlilik bağının kurulmasıyla beraber aile yaşam döngüsü başlar. Aile yaşam döngüsünün, sağlıklı olarak ilerlemesinde evlilik ilişkisinden sağlanan doyum çok önemlidir. "Çünkü evlilik, mutlulukları, güçlükleri, sevinçleri, zorlukları ve yararları ile insan yaşamını pek çok yönü ile etkileyen, bireylerin genel sağlık durumunu iyileştiren ve yaşamdan doyum almalarını destekleyen sosyal bir kurum" niteliğindedir. ${ }^{6}$ Evlilik doyumu, evlilik ilişkisinin, bireyin ihtiyaç ve beklentilerini ne ölçüde karşıladığını göstermektedir. Başka bir deyişle, "bireyin kendi evlilik ilişkisindeki gereksinimlerini, taleplerini karşılama derecesine yönelik algısı" olarak tanımlanmaktadır. ${ }^{2}$ Evlilik ilişkisinin işlevselliğinde, bireyin sevme, sevilme, ait olma, önemli ve değerli bulunma, cinsellik ve sadakat gibi temel ihtiyaçlarını karşılayıp karşılamadığını ifade etmek için de bu kavram kullanılmaktadır. ${ }^{7,8}$ Evlilik doyumunu ele alan teorilere bakıldığında, sevginin evrimi, problem çözme, sosyal mübadele ve yükleme kuramlarının literatürde yer aldı ğ görülmektedir. Sevginin evrimi kuramı; evlilik doyumunu cinsellik ve üreme ile açıklamakta ve cinsel dürtünün en önemli amacinın çoğalma olduğunu ifade etmektedir. Buna göre, erkekte tek eşlilik önemli değildir; çünkü erkek fazla sayıda çocuk sahibi olmak ister. Kadının ise önceliği, çocuklarına iyi babalık yapacak bir erkek seçmektir. Fakat evlilik yaşamı içerisinde bu ihtiyaçlar cinsellikten sevgiye evrilir. ${ }^{9}$ Problem çözme kuramında, evlilik ilișkisinde probleme neden olan cinsel sorunlar, iletişim sorunları, çocuk sahibi olamama, ruhsal hastalıklar, ekonomik güçlükler, kök aile ile çatışmalı ilişkiler gibi sorunlar çözüldüğünde eşlerin evlilikten doyum sağlayacağı ifade edilir. ${ }^{8}$ Sosyal mübadele kuramı, birey içinde bulunduğu ilişkiden doyum almasa bile bağımlılık düzeyinin yüksek olması nedeniyle bu ilişkiyi sürdürmek isteyip istememesini araştırır. ${ }^{10}$ Buna göre, eşlerin ilişkilerinde karşılıklı olarak çeşitli faydalar sağlamaları sonucu doyum oluşacağı ifade edilmektedir. Bireylerin, ilişkilerinde elde bedelden daha çok fayda sağlaması da ilişkilerini doyum sağlayıcı olarak değerlendirmesini sağlamaktadır. ${ }^{11}$ Yükleme kuramında ise, insanların "neden" 
sorusuna verdiği yanıtlar önemlidir. Evlilik doyumunun da neden sorusunun yanıtı bağlamında; uzlaşma, uyma, problem çözme ve hedef belirleme gibi bilişsel süreçlerle açıklanabileceğini savunmaktadır. ${ }^{1}$

\section{Hastalıkların Evlilik Doyumuna Etkisi}

Kronik hastalıklar, tüm dünya ülkelerinde demografik ve epidemiyolojik dönüşümün ve farklılaşmanın sonucu olarak hızla artmakta ve küresel bir halk sağlığı sorunu halini almaktadır. $\mathrm{Bu}$ durum, hem kronik hastalıkların çeşitlenmesini, hem de kronik hastalığa sahip olan bireylerin sayısının artışını beraberinde getirmiştir. Kronik hastalıkların varlığı, yalnızca tıbbi açıdan değil aynı zamanda hastalı tanısı alan bireyin ve etkileşim içerisinde olduğu çevredeki insanlar açısından da fiziksel, psikolojik, sosyal ve ekonomik yönden pek çok güçlük yaratmaktadır. ${ }^{12}$

Güçlük yaratan noktalardan biri olan evlilik doyumu da, bireylerin sağlık durumuyla yakından ilişkilidir. Kronik hastalıkların varlığı, eş ilişkisinde biyopsikososyal ve ekonomik sorunların ortaya çıkmasına zemin hazırlayabilir. Kronik hastalık karşısında ailenin tepkileri, hastalığın ciddiyetine veya sonrasında ortaya çıkan kayıplara göre farklılaşabilir. Bu yönüyle, aile içi etkileşimde değişimlerin olması kaçınılmazdır. Aile üyelerinde meydana gelen bu değişim, eşlerin gelişim dönemi açısından bireyin ve ailenin gelişimsel dönemine özgü yaşam deneyimlerinin ve kök aile ile sosyal yaşam tarafindan öngörülen karmaşık ve uzun vadeli olarak hastalığa yüklenen anlamın bir sonucu olarak değerlendirilebilir. Hastalık teşhisiyle beraber kriz yaşayan kimi aileler, yeterince hazırlanmadıkları yaşamın yeni bir boyutuna taşınarak ve kaynak bulma, destek sağlama, problem çözme ve baş etme becerileri yönünden güçsüz duruma gelebilir. ${ }^{13}$

Kronik hastalıklarda yaşanan psikososyal süreçler, sağlık ve tam iyilik halinin sağlanmasında temel rol oynar. Bu süreçler, bireyin sağlık ve hastalığa yönelik inançları, beden algısı, kendilik algısı ve yaşam beklentisinden etkilenir. ${ }^{14}$ Kronik hastalıklar, psikolojik ve sosyal yönden hem hasta olan bireyi hem de aileyi etkilemektedir. Hastalık tanısı almış olan birey ve aile üyelerinde hastalığa karşı verilen tepkiler farklı şekillerde, sürelerde ve düzeylerde olabilmekle beraber sıklıkla inkâr etme, şok, öfke duyma, pazarlık etme, depresyon ve son olarak kabul etme ve bakıma entegre olma aşamaları yaşanmaktadır. ${ }^{15} \mathrm{Bu}$ süreçte, kronik hastalığa sahip bireylerin evliliklerinde kriz oluşturabilir. Çiftler, bu deneyime dair bilişsel şemalar ve bununla beraber duygu üretimine yönelebilir; "teste tabi tutuldukları" algısına kapılabilirler. Öte yandan sosyal desteğin güçlü olduğu ailelerde, hastalıkla baş etmede aile üyeleri kendilerini daha güçlü hissedebilir. Örneğin, aile üyelerinin onları çok sevdiğini, böylece hastalıkla ilgili sorunlar veya talepler ne olursa olsun onlara her zaman bakacaklarını, yaşanacak güçlükler karşısında birbirlerini asla terk etmeyeceklerini, yeterli finansman mevcutsa ve çaba gösterilirse, tıbbi kaynakların erişilebilir olduğunu ve hastalığın iyileştirilebileceğini düşünebilir.

Kronik hastalık, hem hastalık tanısı alan birey, hem de diğer aile bireyleri için uzun süreli stres kaynağıdır. $\mathrm{Bu}$ kronik stresin niteliği ve yoğunluğu üç önemli belirleyiciye sahiptir. İlki; hasta ve aile bireylerinin günlük aktivitelerinde gereken değişikliklerin büyüklüğüdür. Hastalık karşısında, hastanın sağlığını ve iyilik halini optimize etmek için gereken değişiklikler, her hastalığın özelliğinin farklı olmasından dolayı farklı sorunları gündeme getirebilir. Hastalıktan kaynaklanan stres düzeyinin ikinci belirleyicisi, hastanın ailesinin yaşam koşulları ve bu koşullar içindeki değişim yapabilme kapasitesidir. Bu noktada anne babalar, eşler ve diğer aile üyeleri birincil destek kaynağı olarak kabul edilir. Fakat hane halk1 üyeleri, beklenenden daha az yardım sağlayabilir veya kendileri de bu süreçte yardıma ihtiyaç duyabilir. Bu durum da, bakım veren yükü olarak ifade edilen farklı bir sorunu meydana getirir. Son olarak, kronik hastalığı olan bireyin desteklenmesi için tıbbi yardım ve gereksinim duyulan kaynaklara (ilaç, tıbbi malzeme, ambulans hizmetleri, evde bakım hizmetleri gibi) erişim, hastalığın stresini hafifletebilir veya şiddetlendirebilir. ${ }^{13}$ Tüm bu süreçte yaşanan psikososyal, ekonomik değişimler ve güçlükler, evlilik doyumunu azaltıcı etkiye sahip olmaktadır. Fakat, karşılaşılan güçlüklerle baş etmek için destek mekanizmalarının işlevsel olması, evlilik doyumunu arttırmada önemli bir faktördür. ${ }^{16}$ Aksi halde doyumun azalmasıyla beraber, evlilik yemininde yer alan "hastalıkta ve sağlıkta" sözü işlevini yitirerek ailenin parçalanmasına sebep olabilir.

Ailede, kronik hastalıklar karşısında yaşanan değişim sürecine, sağlıklı uyum sağlamanın anahtarı çoğunlukla bireysel ve kolektif olarak aile üyelerinin dayanıklı ve sorunların çözümünde etkili olabilmeleriyle yani direnç göstermeyle ilişkidir. Aile direnci; ailenin 
değişim karşısında bozulmaya ve kriz durumlarına karşı esnek ve uyarlanabilir olmalarına yardımcı olan boyutları ve özellikleri olarak tanımlanabilir. Başka bir deyişle, aile direnci, bir ailenin şimdi veya gelecekte stres karşısında uyum sağlama, başa çıkma ve sorun çözme yolunu ifade etmektedir. Direnci yüksek olan dayanıklı aileler, gelişim düzeyi, risk ve koruyucu faktörlerin etkileşimine bağlı olarak stresli yaşam olayları karşısında olumlu yanıt verir. ${ }^{13}$ Fakat pek çok aile, hasta bir üyenin varlığından kaynaklanan güçlüklerle başa çıkarken savunmasızdır. Ailede yeterli sosyal destek sisteminin olmaması, aile içi çatışmalar, aile üyelerinin deneyimlediği çeşitli olumsuz yaşam olayları (işsizlik, göç, bağımlılık ve iflas gibi) bir hastalığın yarattığı krizle birleştiğinde, eşler arasındaki ilişki bozulmakta ve evlilik doyumu azalmaktadır. $\mathrm{Bu}$ risk faktörlerine karşılık, birçok ailede hasta olan bireyle kolayca bağlantı kurabilme ve ihtiyaçların karşılanmasında destekleme ve ilgi gösterme davranışlarının olduğu görülür. Eşler arasında, birbirleriyle doğrudan iletişim kurma, beraber serbest zaman aktiviteleri yapabilmek için zaman ayırma, sağlık profesyonelleriyle güvenilir ilişki kurma ve etkili problem çözme becerisi evlilik doyumunun artmasını sağlayabilir.

Kronik hastalıklarda, evlilik doyumunu etkileyen faktörlere bakıldığında evliliğe ve hastalığa ilişkin özelliklerin belirleyici olduğu görülmektedir. Bu bağlamda aile öyküsü, eşler arası iletişim ve etkileşim, hangi eşin hasta olduğu, hastalığın yapısı ve türü ile başa çıkma becerisi ele alınabilir:

- $\quad$ Aile Öyküsü: Hastalık bakış açısıyla aile öyküsü, aile üyelerinin biyopsikososyal sağlığını ve ailenin hastalıklar açısından yaşadığı önceki krizlerden nasıl etkilendiğini içerir. Olumsuz deneyimler yaşayan ve hastalıklar karşısında fonksiyonel olmayan ailelerde hastalık bir kriz durumu yaratarak dengeyi bozabilir. ${ }^{18}$

- Eşler Arasındaki İletişim ve Etkileşim: Eşler arasında besleyici, iyi yapılandırılmış, açık ve net, eleştiri alma ve verme korkusu olmadan duyguları ifade etme özgürlüğünü barındıran iletişim ve etkileşim yapısı hastalığın neden olduğu sorunlarla başa çıkabilme potansiyelini beraberinde getirir. Buna karşın, aile üyelerinin çatışmalı, çelişkili, suçlayıcı ve yıkıcı bir iletişim kalıbına sahip olmaları sosyal desteğin sağlanmasında zorluklar yaramakta ve evlilik doyumunu azaltmaktadır. ${ }^{19}$

- Hangi Eşin Hasta Olduğu: Heteroseksüel evliliklerde, kadının veya erkeğin hastalık tanısı alması, başka bir deyişle hangi eşin hasta olduğu, farklı ailede, farklı durumların yaşanmasına sebep olabilir. Örneğin, bir koca ve baba rolündeki erkeğin istihdam statüsünde radikal bir değişime uğrayan ciddi bir hastalık tanısı alması, aile yaşamı üzerinde kalıcı bir etkiye sahip olabilir. ${ }^{20}$ Aynı zamanda, birbirine bağlı olma ve ayrılma korkusu yaşama, umutlar, hayaller ve beklentiler, eşlerden birinde meydana gelen ani bir değişikliğin ortaya çıkardığ 1 kayıpları çevreleyen konulardır.

- Hastalığın Yapısı ve Türü: Hastalığın karakteristik yapısı, tedavi şekli, süresi ve birey üzerinde yarattığı etki gibi pek çok etken evlilik doyumunu da etkileme potansiyeline sahiptir.

- Başa Çıkma Becerisi: Başa çıkma, bireyin kişisel kaynakları ötesinde görülen stres yaratan koşulları yönetme ve yönlendirme sürecidir. Aile perspektifinde başa çıkma davranışları ise, aile üyelerinin hastalığın yol açtığ aile hayatındaki değişime nasıl tepki verdiğinin bir ifadesini temsil eder. Hastalığa sahip olan bireylerin, stres etkenleri karşısında başa çıkma stratejileri, sorun çözme becerileri ve uyum kapasiteleri yetersiz olduğunda ortaya çıkan stresin olumsuz etkileri, bağışıklık sistemindeki mekanizmalara olumsuz şekilde yansımakta ve böylece hastalığa bağlı ataklar ortaya çıkmaktadır. ${ }^{17}$

\section{Behçet Hastalığı ve Ailevi Akdeniz Ateşi Hastalığı}

Behçet hastalığı, "Ataklarla seyreden, tekrarlayan oral aft ve genital ülserler ile göz bulgularının yanı sıra kas-iskelet, nörolojik, solunum ve gastrointestinal sistem tutulumları gösteren, geniş dağılımlı bir vaskülittir". Ataklar şeklinde yatışma (remisyon) ve alevlenmeler (relaps) ile meydana gelmekte olup, bulaşıcı değildir. Spesifik bir laboratuvar bulgusu olmadığından dolayı, teşhis hastadaki semptomlara bakılarak konulmakta ve bu nedenle hastalığın fark edilmesi güçleşmektedir. Hastalık sonucu en yaygın görülen morbidite nedeni, göz tutulumlarına bağlı körlüğün gelişmesi ve organ kayıplarıdır. Özellikle, nörolojik sistem ile sindirim 
sisteminde oluşan tutulumlar ise en sık görülen ölüm nedenidir. Behçet hastalığı dünya çapında görülebilmektedir. Yapılan epidemiyolojik çalışmalarda, hastalığın en sık İpek Yolu üzerinde bulunan ülkelerde yaşayan insanlarda görülmesi nedeniyle hastalık, "İpek Yolu Hastalığgı" olarak da isimlendirilir. Dünya çapında hastalığın dağılımına bakıldığında ise, en sık Türkiye'de görüldüğü belirlenmiştir. Hastalık, genellikle 20'li ve 30'lu yaşlarda başlamakla beraber kadın ve erkeklerde görülme sıklığı eşittir. ${ }^{21,22}$

Ailevi Akdeniz Ateşi (FMF) ise "ataklarla seyreden karın, göğüs veya eklem ağrılarının eşlik ettiği ateş nöbetleri ile karakterize olan" kronik bir bağışıklık sistemi hastalığıdır. Hastalık, genetik mutasyonlara bağlı olarak gelişmekte olup soybağı ile aktarılmaktadır. FMF, Türkiye'nin de içinde bulunduğu Doğu Akdeniz Ülkelerinde yaşayan bireylerde daha sık görülür. Çocuklarda ortalama hastalık başlangıç yaşı dörttür. Yakınmalar, hastaların $\% 65$ 'inde hayatın ilk on yılında, \%90'ında ise ilk 20 yılında ortaya çıkar. Erkeklerde, kadınlara oranla üç kat daha sık görülür. FMF hastalığında iyileşme süreci hızlıdır, fakat atak sıklığ 1 haftada birden yılda bire kadar farklı aralıklarda olabilir. Atakları başlatan net bir etken yoktur ancak atakların menstrüasyon, duygusal stres veya ağır fiziksel aktivite dönemlerine rastladığı görülmüştür. Ataklar, çoğunlukla herhangi bir ön bulgu vermeden aniden ortaya çıkar ve kendiliğinden kaybolur. Ataklar arasında ise, hastalarda hiçbir fiziksel belirti görülmez. ${ }^{23,24}$

Kronik hastalıklar, sisteme girerek kriz yaratan, ilişkileri etkileyen, dengenin yeniden kurulmasinı gerektiren bir olgudur. $\mathrm{Bu}$ durumda, çiftler arasındaki evlilik ilişkisinden sağlanan doyum da etkilenmektedir. $\mathrm{Bu}$ doğrultuda çalışmanın amacı, Behçet Hastalığı ile Ailevi Akdeniz Ateşi Hastalığı (FMF) tanısı almış olan çiftlerin evlilik doyumunun irdelenmesidir.

\section{YÖNTEM}

Genel tarama modelinde tasarlanan bu araştırmada, Behçet ve Ailevi Akdeniz Ateşi Hastaları Derneği'ne kayıtlı olan en az biri Behçet hastalığı ve FMF tanısı alan 68 evli çift ile çalışılmıştır. Veriler 20 Şubat 2017- 1 Haziran 2017 tarihleri arasında elde edilmiş olup, araştırma kesitsel bir çalışmadır. Araştırmada, veriler dernekte düzenlenen Uzman-Hasta Buluşmalarında Konya ve
Ankara'da toplanmıştır. Veri toplamak amacıyla araştırmacılar tarafından hazırlanan soru kâğıdı ile Golombok-Rust Evlilik Durumu Envanteri kullanılmıştır.

Soru Kâğıdı: Araştırmacılar tarafindan, literatür taramasına dayanılarak hazırlanan form 2 bölümden oluşmaktadır. İlk bölümde hastaların ve eşlerin sosyo-demografik özellikleri ve hastalığa dair bilgileri belirlemek amacıyla, katılımcılara yöneltilen 43 soru mevcuttur. İkinci bölümde ise, hastalık sonrasında aile ilişkileri ve sosyal çevre ile olan ilişkilerin nasıl değiştiğini belirlemek üzere 3'lü Likert tipinde yanitlanabilecek 13 soru bulunmaktadır.

Golombok-Rust Evlilik Durumu Envanteri (GREDE): Evli veya beraber yaşayan çiftler arasındaki ilişkinin kalitesini değerlendirmek amaciyla kullanılan GREDE; Rust, Bennun, Crowe ve Golombok (1990) tarafindan geliştirilmiştir. Türkçe'ye geçerlik ve güvenirlik çalışması ise 2014 yılında Duyan ve Çamur Duyan tarafindan yapılmıştır. 28 maddeden oluşan GREDE, eşler arasındaki cinsel ilişkiyi içermeden, evlilik durumunu değerlendiren tek boyutlu bir ölçme arac1 niteliğinde olup, daha önceden yayınlanmış olan Golombok Rust Cinsel Doyum Envanteri'nin (GRISS) yardimcisidır. GREDE'deki maddeler, ilişkiden tatmin olma, iletişim, ortak ilgiler, güven ve saygı alanlarını içermekte olup tek boyuttan oluşmaktadır. Ölçekten alınan düşük puanlar, evlilik doyumunun yüksek; yüksek puanlar ise evlilik doyumunun düşük ve ilişkideki sorunların ciddi olduğu anlamına gelmektedir (Duyan ve Çamur Duyan, 2014). Buna göre 16 puan ve daha düşük ise tanımsız, 17-21 puan "çok iyi", 22-25 puan arasında "iyi”, 26-29 arasında "vasatın üstünde", 30-33 arasında "vasat", 3437 arasında "zayıf", 38-41 arasında "kötü", 4246 arasında "ciddi sorunlar" ve 47 ve üstünde puanlar "çok ciddi sorunları" işaret etmektedir.

Araştırma kapsamında elde edilen veriler, SPSS 22.0 paket programına girilmiş ve uygun tanımlayıcı istatistiki teknikler kullanılarak analiz edilmiştir.

\section{BULGULAR}

Araştırma bulguları, sosyodemografik ve evliliğe dair özellikler ile evlilik doyumunu ele alan iki kısımda aktarılacaktır. Katılımcıların sosyoekonomik özelliklerine ilişkin bulgular tablo 1 'de yer almaktadır. 


\begin{tabular}{|c|c|c|}
\hline & Sayı & Yüzde \\
\hline \multicolumn{3}{|l|}{ Yaş grubu } \\
\hline $25-30$ yaş & 23 & 16,9 \\
\hline $31-35$ yaş & 33 & 24,3 \\
\hline $36-40$ yaş & 28 & 20,6 \\
\hline 41-45 yaş & 15 & 11 \\
\hline $46-50$ yaş & 19 & 14 \\
\hline 51 Yaş ve Üstü & 18 & 13,2 \\
\hline \multicolumn{3}{|l|}{ Ĕ̆itim } \\
\hline İlkokul & 8 & 5,9 \\
\hline Ortaokul & 17 & 12,5 \\
\hline Lise & 45 & 33,1 \\
\hline Önlisans ve Lisans & 58 & 42,6 \\
\hline Lisansüstü & 8 & 5,9 \\
\hline \multicolumn{3}{|l|}{ Gelir dağılımı } \\
\hline $0-1000$ tl aras & 34 & 25 \\
\hline $1001 \mathrm{tl}-1999 \mathrm{tl}$ aras1 & 21 & 15,4 \\
\hline $2000 \mathrm{tl}-2499 \mathrm{tl}$ aras1 & 27 & 19,9 \\
\hline $2500 \mathrm{tl}-2999 \mathrm{tl}$ aras 1 & 18 & 13,2 \\
\hline 3000 TL ve Üstü & 36 & 26,5 \\
\hline \multicolumn{3}{|l|}{ Yasama yeri } \\
\hline Konya & 89 & 65,4 \\
\hline Ankara & 47 & 34,6 \\
\hline \multicolumn{3}{|l|}{ Hastalıklar } \\
\hline FMF hastalığ 1 & 45 & 33,1 \\
\hline Behçet hastalığ1 & 23 & 16,9 \\
\hline Diğer & 16 & 11,8 \\
\hline Yok & 52 & 38,2 \\
\hline \multicolumn{3}{|c|}{ Hastalığı deneyimleme süresi } \\
\hline 1 yildan az & 4 & 5 \\
\hline $1-5 \mathrm{y} 11$ & 22 & 26 \\
\hline $6-10 \mathrm{y} 11$ & 15 & 18 \\
\hline $11-15$ y1l & 8 & 10 \\
\hline 15 Y1l ve Üstü & 35 & 42 \\
\hline
\end{tabular}

Buna göre katılımcıların \%16,9'u (n=23) 2530 yaş, \%24,3'ü $(n=33)$ 31-35 yaş, \%20,6's1 $(\mathrm{n}=28) \quad 36-40$ yaş, \%11'i $(\mathrm{n}=15)$ 41-45 yaş, $\% 14$ 'ü $(n=19) \quad 46-50$ yaş ve $\% 13,2$ 'si $(n=18)$ ise 51 yaş ve üstü gruptadır. Katılımcıların $\% 5,9^{\prime} u \quad(n=8) \quad$ ilkokul, \%12,5'i $\quad(n=17)$ ortaokul, \%33,1'i (n=45) lise, \%42,6's1 ( $=58)$ önlisans veya lisans ve $\% 5,9^{\prime} \mathrm{u}(\mathrm{n}=8)$ lisansüstü mezunudur. Katılımcıların istihdam alanları değerlendirildiğinde, \%46,3'ü $(\mathrm{n}=63)$ kamu, $\% 27,9^{\prime}$ u $(\mathrm{n}=38)$ özel sektörde çalışmaktadır. $\% 22,7$ 'si $(n=31)$ ise ev hanımı olup \%2,9'u $(\mathrm{n}=4)$ ise işsizdir. Gelir durumlarına göre dağılımda ise, katılımcıların \%25'i $(n=34) 0$ 1000 TL, \%15,4'ü (n=21) 1001 TL-1999 TL, \%19,9'u (n=27) 2000 TL-2499 TL, \%13,2'si $(\mathrm{n}=18) 2500$ TL-2999 TL ve \%26,5'i $(\mathrm{n}=36)$ 3000 TL ve üstü gelir grubunda yer almaktadır. \%97,1'si $(\mathrm{n}=132)$ gelirlerinin, giderlerini karşıladığını belirtmiştir. Katılımcıların \%65,4'ü $(n=89)$ Konya ve \%34,6's1 (n=47) Ankara'da yaşamaktadır. Katılımcıların hastalık tanılarına bakıldığında \%38,2'sinin $(\mathrm{n}=52)$ hastalığg yokken; \%33,1'i $(\mathrm{n}=45)$ FMF, \%16,9'u (n=23) Behçet Hastalı̆̆ ve $\% 11,8$ 'i $(n=16)$ tansiyon, diyabet, guatr gibi diğer hastalık tanılarını almıştır. Bununla beraber, katılımcıların \%15,4'ünün $(n=21)$ ruhsal hastalığa sahip olduğu ve \%6,6'sının $(n=9)$ engelli olduğu belirlenmiştir. Katılımciların \%64,7'sinin $\quad(n=88), \quad$ aile üyelerinde hastalık tanısı alan bireylerin olduğu belirtilmiştir. Hastalık tanısı alan 84 katılımcinın \%5'i (n=4) 1 yıldan az, \%26's1 $(\mathrm{n}=22)$ 1-5 y1l, \%18'si (n=15) 6-10 y1l, \%10'u $(n=8) \quad 11-15$ yil ve \%42'si $(n=35) 15$ y1l ve daha fazla süredir hastalığ deneyimlemektedir. Hastalık tanısı alan katılımcıların \%43'ü $(\mathrm{n}=36)$ hastaneye yatmadıklarını; \%23'ü $(n=19)$ bir kez ve \%35'i $(n=29)$ iki ve daha fazla kez hastaneye yattıklarını belirtmiştir. 


\begin{tabular}{|l|l|l|}
\hline Tablo 2. Evliliğe ilişkin bilgiler & Sayı & Yüzde \\
\hline Evlenme şekli & 94 & 69,1 \\
\hline İsteyerek & 42 & 30,9 \\
\hline Görücü usulü & & \\
\hline Evlilik süresi & 28 & 20,6 \\
\hline $1-5$ yıl & 24 & 17,6 \\
\hline $6-10$ yıl & 24 & 17,6 \\
\hline $11-15$ yıl & 60 & 44,1 \\
\hline 16 ve üstü & & \\
\hline Çocuk sahibi olma & 61 & 89,7 \\
\hline Var & 7 & 10,3 \\
\hline Yok & & \\
\hline Kaçıncı evlilik & 130 & 95,6 \\
\hline Birinci & 6 & 4,4 \\
\hline İkinci & & \\
\hline
\end{tabular}

\begin{tabular}{|l|l|l|}
\hline \multicolumn{3}{|l|}{ Tablo 3. Golombok-Rust Evlilik Durumu Envanterinden (GREDE) alınan puanların dağılımı } \\
\hline & Sayı & Yüzde \\
\hline Tanımsız & 6 & 4,4 \\
\hline Cok iyi & 19 & 14,0 \\
\hline İyi & 15 & 11,0 \\
\hline Vasat üstü & 9 & 6,6 \\
\hline Vasat & 28 & 20,6 \\
\hline Zayıf & 11 & 8,1 \\
\hline Kötü & 22 & 16,2 \\
\hline Ciddi sorunlar & 12 & 8,8 \\
\hline Çok ciddi sorunlar & 14 & 10,3 \\
\hline Toplam & $\mathbf{1 3 6}$ & $\mathbf{1 0 0 , 0}$ \\
\hline & &
\end{tabular}

Katılımcıların, evliliklerine ilişkin bulgular tablo 2'de gösterilmektedir. Buna göre katılımcıların tamamı resmi nikâhla evli olup, çiftlerin evlenme şekli incelendiğinde $\% 69,1$ 'inin ( $\mathrm{n}=94)$ isteyerek ve \%30,9'unun $(n=42)$ ise görücü usulü ile evlendikleri Golombok-Rust Evlilik Durumu Envanterinden (GREDE) alınan puanların dağılımı tablo 3 'te yer almaktadır. Buna göre, katılımciların \%4,4'ü (n=6) tanımsız, \% 14'ü $(n=19)$ çok iyi ve \%11'i $(n=15)$ iyi olarak tanımlanan puanlar almıştır. Diğer yandan, katılımciların \%6,6's1 (n=9) vasat üstü, $\% 20,6$ 's1 $(n=28)$ vasat ve $\% 8,1$ 'i $(n=1)$ zayif puan aralığında yer almıştır. Katılımcıların \% 16,2 'si ise $(\mathrm{n}=22)$ kötü, $\% 8,8^{\prime} \mathrm{i}(\mathrm{n}=12)$ ciddi sorunlar ve $\% 10,3$ 'ü $(n=14)$ çok ciddi sorunları işaret eden puanlar elde etmişlerdir.

Behçet ve FMF Hastalığı tanısı alan çiftlerin, aile ve sosyal çevreyle ilişkilerine ilişkin bulgular tablo 4 'te gösterilmiștir. Buna göre hastalık sonrasında aile içi ilişkiler açısından, katılımcıların \%52,2'si (n=71) ilişkilerin değişmediğini; \%33,1'i $(n=45)$ bozulduğunu ifade etmiştir. Aile düzeni açısından bakıldığında \%55,9'u (n=76) değişmediğini, $\% 23,5$ 'i $(n=32)$ güçlendiğini ve \%20,6'sının $(n=28)$ bozulduğunu ifade etmiştir. Komşuluk ilişkilerine odaklanıldığında, katılımcıların görülmektedir. Çiftlerin \%20,6'sının ( $\mathrm{n}=28)$ evlilik süresi 1-5 yıl, \%17,6'sının (n=24) 6-10 y1l ve $11-15$ yil $(n=24)$ ve $\% 44,1$ 'inin $(n=60)$ 16 yıl ve üstü olarak belirlenmiştir. Çiftlerin $\% 89,7$ 'sinin $(\mathrm{n}=61)$ çocuğu vardır ve \%95,6'sı $(\mathrm{n}=130)$ birinci evliliklerini yapmıştır.

$\% 66,2$ 'sinin $\quad(\mathrm{n}=90)$ hastalı sonrasinda komşularıyla ilişkilerinin değişmediğini, $\% 18,4$ 'ünün $\quad(\mathrm{n}=25)$ bozulduğunu ve $\% 15,4$ 'ünün $(\mathrm{n}=21)$ güçlendiğini belirtmiştir. Arkadaşlık ilişkileri değerlendirildiğginde ise, katılımciların \%49,3'ünün $\quad(n=67)$ arkadaşlarıyla ilişkilerinin değişmediğini, $\% 31,6$ 'sinın $\quad(n=43)$ bozulduğunu ve $\% 19,1$ 'inin $\quad(n=26)$ güçlendiğini düşündüğü görülmektedir. Behçet ve FMF hastalığı tanısı alan çiftlerin, aile içi ilişkilerine ilişkin bulgulara bakıldığında ise hastalık sonrası katılımcıların \%24,3'ü $(n=33)$ aile üyeleriyle birlikte gezmeye gitmenin azaldığını; \%12'5'i $(\mathrm{n}=1)$ aile üyeleriyle sohbet etmenin azaldığını, $\% 13,2$ 'si $\quad(\mathrm{n}=18)$ aile üyeleriyle önemli konuları paylaşmanın azaldığını ve $\% 8,1^{\prime} \mathrm{i}$ $(\mathrm{n}=11)$ arttığını; \%30,1'i $(\mathrm{n}=41)$ aile üyelerine küçük düşürücü söz söyleme davranışlarının azaldığını ve \%12,5'inin (n=17) arttığını; $\% 28,7$ 'sinin $(\mathrm{n}=39)$ aile üyelerinin birbirine destek olmasında arttı̆̆ını; \%29,4'ünün $(n=40)$ aile üyeleri arasında kırgınlığın azaldığını ve 


\begin{tabular}{|c|c|c|}
\hline Aile üyeleriyle birlikte gezmeye gitme & Sayı & Yüzde \\
\hline Azald 1 & 33 & 24,3 \\
\hline Değişmedi & 98 & 72,1 \\
\hline Artt1 & 5 & 3,7 \\
\hline \multicolumn{3}{|l|}{ Aile üyeleriyle sohbet etme } \\
\hline Azald 1 & 17 & 12,5 \\
\hline Değişmedi & 115 & 84,6 \\
\hline Artt1 & 4 & 2,9 \\
\hline \multicolumn{3}{|l|}{ Aile üyeleriyle önemli konuları paylaşma } \\
\hline Azaldı & 18 & 13,2 \\
\hline Değişmedi & 107 & 78,7 \\
\hline Arttı & 11 & 8,1 \\
\hline \multicolumn{3}{|l|}{ Aile üyelerine küçük düşürücü söz söyleme } \\
\hline Azald 1 & 41 & 30,1 \\
\hline Değişmedi & 78 & 57,4 \\
\hline Artt1 & 17 & 12,5 \\
\hline \multicolumn{3}{|l|}{ Aile üyelerinin birbirine destek olması } \\
\hline Azald 1 & 24 & 17,6 \\
\hline Değişmedi & 73 & 53,7 \\
\hline Artt1 & 39 & 28,7 \\
\hline \multicolumn{3}{|l|}{ Aile üyeleri arasında kırgınlık } \\
\hline Azald 1 & 40 & 29,4 \\
\hline Değişmedi & 71 & 52,2 \\
\hline Artt1 & 25 & 18,4 \\
\hline \multicolumn{3}{|l|}{ Aile üyelerine karşı şiddet uygulama } \\
\hline Ailede şiddet yoktur & 130 & 95,6 \\
\hline Azald1 & 3 & 2,2 \\
\hline Değişmedi & 3 & 2,2 \\
\hline \multicolumn{3}{|l|}{ Eşle cinsel ilişki sıklığı } \\
\hline Azald 1 & 81 & 59,6 \\
\hline Değişmedi & 51 & 37,5 \\
\hline Artt1 & 4 & 2,9 \\
\hline
\end{tabular}

\%18,4'ünün $(\mathrm{n}=25)$ arttığını ve eşle cinsel ilişkiler boyutunda katılımcıların \%59,6's1 $(n=81)$ cinsel ilişki sıklığının azaldığını ifade etmiştir.

\section{TARTIŞMA}

Kronik hastalıklar hem aile ilişkilerinde, hem de sosyal çevre ile olan ilişkilerde sorunların oluşmasına neden olabilir. Örneğin, hastalığın neden olduğu kisitlamalar ve tedavinin gereklilikleri ailedeki rolleri ve günlük rutinleri değiştirebilir. Aile üyeleri, suçluluk, öfke, hüzün, korku, kaygı ve çökkünlük gibi olumsuz duygular yaşayabilir. $\mathrm{Bu}$ açıdan bakıldığında ailenin yaşam kalitesi ve evlilik doyumu etkilenebilir. Golics ve arkadaşlarının çeşitli kronik hastalıklara sahip olan 133 aile ile yaptığı çalışmada, ${ }^{25}$ özellikle bakım veren aile üyeleri arasında, günlük aktivitelerde çalışma yaşamı olumsuz olarak etkilendiği için, ekonomik ve sosyal ilişkiler ciddi şekilde olumsuz etkilenmekte ve ailenin yaşam kalitesi azalmaktadır. Lahat ve arkadaşlarının ${ }^{26}$ ise, Behçet ve FMF hastalığ hastalıklar grubunda yer alan Chron hastas1 olan 134 kişiyle yaptıkları araştırmada, katılımcıların \%70'i tedavi sürecine aile üyelerinin desteğinin hastalıkla daha iyi başa çıkmalarına yardımcı olabileceğini ifade etse de, bu süreçte aile içi ilişkilerin olumsuz etkilendiği belirtilmiştir. Kronik hastalıkların, aileyi böylesine derinden etkilemesine karşın, literatürde Behçet ve FMF hastalarının aile ilişkilerini odak alan çalışmaların kısıtlı olduğu görülmektedir. 
Örneğin, Behçet hastalarının aileleriyle olan ilişkisini ele alan Okyayuz'un ${ }^{27} 34$ kanser ve 37 Behçet Hastasının ailelerini incelediği çalışmada, Behçet Hastalarının aile işlevlerinde belirgin bozulmaların olduğu ifade edilmektedir. Aile üyeleri arasında, şiddet ve kırgınlık, sağlıksız işlev gösteren aileleri işaret eden en önemli unsurlardandır. $\mathrm{Bu}$ aileler, aralarındaki çatışmaları çözmekte güçlük çeker. Fakat özellikle hastalık gibi hem hastalık tanısı alan bireyde hem de diğer aile üyelerinde strese ve krize neden olabilme potansiyeli olduğunda bu çatışmaların çözmeleri beklenir. Hastalık sonrasında ise, aile üyeleri arasındaki ilişkilere bakıldığında kırgınlık ve şiddetin arttığına dair sonuçlara ulaşılmıştır. $\mathrm{Bu}$ araştırma kapsamında, hastalık sonrasında aile ve sosyal çevre ile ilişkiler; genel olarak aile içi ilişkiler, aile düzeni, komşuluk ilişkileri ve arkadaşlık ilişkileri bağlamında geniş açıdan irdelenmiştir. İlk olarak, hastalık sonrasında aile içi ilişkiler ele alındığında, katılımcıların önemli bir bölümü aile içi ilişkilerin ve aile düzeninin bozulduğunu ifade etmiştir. Elde edilen bu bilgiyle, hastalık tanısı almanın aile işlevlerini olumsuz etkileme potansiyelinin olduğu söylenebilir. Buradan hareketle, araştırma sonucunda elde edilen bu bulguların Okyayuz'un $^{27}$ çalışmasıyla benzerlik gösterdiği; dahası, bu hastalıkların aile işlevlerinde bozulmalara yol açarak, evlilik doyumunu olumsuz yönde etkilediği ifade edilebilir.

Aile ilişkilerinin yanı sıra, sosyal çevrede yer alan geniş aile üyeleri, akrabalar, arkadaşlar ve komşularla ilişkiler de hastalık durumundan etkilenebilir. Literatürde, Behçet ve FMF hastalıklarına benzer özellikler taşıyan hastalıklara sahip bireylerle yapilan çalışmalarda da sosyal çevre ile ilişkilerin nasıl değiştiğine dair kesin yordayıcıların bulunmadığı görülmektedir. ${ }^{28}$ Örneğin Troy'un ${ }^{29}$ çalışmasında, Crohn ve ülseratif kolit gibi hastalığa sahip olan bireylerin yakın ilişkiler kurmakta zorlandıkları ve sosyal yaşamda izole oldukları ifade edilmektedir. $\mathrm{Bu}$ araştırmada ise, komşuluk ilişkileri açısından konu ele alındığında katılımcıların hastalık sonrasında komşularıyla olan ilişkilerinin değişmediğine, bozulduğuna ve güçlendiğine dair görüşlerinin olduğu görülmektedir. Hastalık sonrasında arkadaşlık ilişkileri değerlendirildiğinde ise komşuluk ilişkilerine benzer biçimde yanıt verdikleri belirlenmiştir. Elde edilen bu bilgi de, tıpkı literatürdeki çalışmalar gibi hastalıkların sosyal çevreyle olan ilişkilere farklı etkilerinin olabileceğini göstermektedir.
Cinsellik insanların fiziksel, psikolojik ve sosyal yaşamının önemli bir parçasıdır. Fakat cinsel işlevlerde meydana gelen bozukluklar, bireyin yakın ilişkiler kurmasını veya bu ilişkilerdeki süreçleri olumsuz olarak etkileyebilme potansiyeline sahiptir. Kronik hastalıkların, cinsel işlevler üzerinde negatif etkilerinin olduğunu ve bu durumun evlilik doyumunu olumsuz etkilediğini gösteren çalışmalar literatürde yer almaktadır. ${ }^{17} \mathrm{Bu}$ noktada, evlilik doyumunda oldukça önemli olan eşle cinsel ilişkiler boyutunda, katılımcıların büyük çoğunluğu cinsel ilişki sıklığının azaldığını ifade etmiştir. Araştırma sonucunda elde edilen bu bulgu, literatürde ortaya konulan çalışmaları desteklemektedir. Örneğin Koçak ve arkadaşlarının, 71 Behçet hastası kadınla yaptıkları çalışmada, cinsel ilişki sıklığında azalma ve cinsel uyarılmada düşüş olduğu belirlenmiştir. ${ }^{30}$ Benzer biçimde, Hiz ve arkadaşlarının, Behçet hastası olan 42 erkekle yaptığı çalışmada, hastalıktan kaynaklanan oral ve genital aftların cinsel işlevi olumsuz yönde etkilediği ortaya konulmuştur. ${ }^{31}$ $\mathrm{Bu}$ çalışmalar 1şı̆̆ında, Behçet ve FMF hastalıkları ortaya çıktığı dönem açısından, cinselliğin ve doğurganlığın en üst düzeyde olduğu dönemde görüldüğü söylenebilir. $\mathrm{Bu}$ doğrultuda, bu çalışmada cinsellik ile hastalık tanısı sonrasında eşler arasındaki ilişki bu araştırmada irdelenmiş ve bu hastalıkların evlilik doyumunu azaltıcı etkisi olduğu görülmüştür.

Golombok-Rust Evlilik Durumu Envanterinden (GREDE) aldığı puanlara bakıldığında, katılımcıların yarısının evlilik doyumlarının düşük olduğunu işaret eden puan aralığında yer aldığı görülmektedir. Evlilik doyumu ve cinsiyet değişkeni arasındaki ilişkiye dair, literatürdeki araştırmalara bakıldığında farklı sonuçlara ulaşıldığı görülmüştür. Bu çalışmada kötü, ciddi sorunlar ve çok ciddi sorunlar puan aralığında kadın eşlerin daha sık yer aldığı görülmektedir. $\mathrm{Bu}$ bulguya göre, kadınların evlilik doyumunun daha düşük olduğu ifade edilebilir.

\section{SONUÇ}

$\mathrm{Bu}$ çalışmada, bireyin evlilik ilişkisindeki gereksinimlerini ve taleplerini karşılama derecesine yönelik algısı olarak tanımlanabilen evlilik doyumu, Behçet ve FMF hastalığı olan çiftlerin evliliği odak alınarak incelenmiştir. Aile ve sosyal çevreyle ilişkiler açısından, hastalık sonrası aile üyeleriyle birlikte gezmeye gitmenin, sohbet etmenin, aile üyeleriyle önemli konuları paylaşmanın, aile üyelerine 
karşı şiddet uygulamanın, aile üyelerinin birbirine desteğinin ve cinsel ilişkinin azaldığı; aile üyeleri arasında kırgınlığın, aile üyelerine küçük düşürücü söz söylemenin arttığ1 sonucuna ulaşılmıştır. Aynı zamanda aile içi ilişkilerle beraber, komşuluk ve arkadaşlık ilişkilerinin de bozulduğu belirlenmiştir. Buradan hareketle, hastalık sonrası meydana gelen değişimler açısından Behçet ve FMF hastalığının aile ve sosyal çevre ile kurulan ilişkiyi olumsuz etkilediği sonucuna ulaşılabilir. Golombok-Rust Evlilik Durumu Envanterinden (GREDE) alınan puanlara bakıldığında, Behçet ve FMF hastalığı tanısı alan bireylerin evlilik doyumunun düşük olduğu sonucuna ulaşılmıştır. Cinsiyet açısından evlilik doyumunda ise, kadınların evlilik doyumunun daha düşük olduğu belirlenmiştir. $\mathrm{Bu}$ veriler 1şı ğında, Behçet ve FMF hasta olan çiftlere aile danışmanlığı, psikoeğitim ve cinsel danışmanlık hizmetlerinden faydalanmaları önerilebilir.

\section{KAYNAKLAR}

1. Cihan Güngör H. Evlilik doyumunu açıklamaya yönelik bir model geliştirme. Yayınlanmamış Doktora Tezi, Gazi Üniversitesi Eğitim Bilimleri Enstitüsü Rehberlik ve Psikolojik Danışmanlık Bilim Dalı, 2007; 1-2.

2. Tezer E. Evlilik ilişkisinden sağlanan doyum: evlilik yaşamı ölçeği. Psikolojik Danışma ve Rehberlik Dergisi 1996; 7 (2): 1-7.

3. Unger DG, Jacobs SB, Cannon C. Social support and marital satisfaction among couples coping with chronic constructive airway disease. Journal of Social and Personal Relationships 1996; 13(1): 123142.

4. Hagedoorn M, Kuijer RG, Buunk BP, Dejong GM, Wobbes T, Sanderman R. Marital satisfaction in patients with cancer: does support from intimate partners benefit those who need it most?. Health Psychology 2000; 19(3): 274.

5. Romero C, Lindsay JE, Dalton WT, Nelson DV. Husbands' perceptions of wives' adjustment to breast cancer: the impact on wives' mood. Psychooncology 2008; 17: 237-43

6. Duyan V, Çamur Duyan G. GolombokRust evlilik durumu envanterinin Türkçe sürümünün bir grup evli çift üzerinde geçerlik ve güvenirlik çalışması. Turkish Journal of Family Medicine and Primary Care 2014; 8(3): 100-107.
7. Erden AD. Kendini izleme tarzı, yakın ilişkilerde yaşanan kaygı ve algılanan eş davranışlarının evlilik doyumu üzerine etkisinin incelenmesi. YayınlanmamışYüksek Lisans Tezi, Ege Üniversitesi, Sosyal Bilimler Enstitüsü Klinik Psikoloji Anabilim Dalı, 2016; 5-8.

8. Kaplan K. Evli bireylerde toplumsal cinsiyet rollerine ilişkin tutumların, evlilik doyumuna ve psikolojik iyi oluş durumuna etkisinin incelenmesi. Yayınlanmamış Yüksek Lisans Tezi, Beykent Üniversitesi, Sosyal Bilimler Enstitüsü Klinik Psikoloji Bilim Dalı, 2016; 15.

9. Buss DM. The evolution of desire. 1st ed.USA: Basic Books; 2005. p.50.

10. Uçak D. Evli çiftlerin kişilik özelliklerinin evlilik doyumu ile ilişkisinin incelenmesi. Yayınlanmamış Yüksek Lisans Tezi, Hasan Kalyoncu Üniversitesi Sosyal Bilimler Enstitüsü Klinik Psikoloji Bilim Dalı, 2015; 7-8.

11. Yalçın Koçkan S. Evli çiftlerde otomatik düşüncelerin ve bilişsel çarpıtmaların evlilik doyumuna etkisinin değerlendirilmesi. Yayınlanmamış Yüksek Lisans Tezi, Üsküdar Üniversitesi Sosyal Bilimler Enstitüsü Uygulamalı Psikoloji Anabilim Dalı, 2015; 11-12.

12. Lynch J, Smith, GD. A life course approach to chronic disease epidemiology. Annual Review of Public Health 2005: 138.

13. Power PW, Orto AE. Perspectives on illness and disability. In Power PW, Orto $\mathrm{AE}$, editor. Families living with chronic illness and disability: interventions, challenges, and opportunities. 1st ed. New York: Springer Publishing; 2004. p. 5-27.

14. Ogden J. Sağlık psikolojisi. Dirlik G. çev.editörleri. 1.bask1. Ankara: Nobel Akademik Yayıncılık; 2016.p. 132-150.

15. Kübler-Ross E, Kessler D. On grief and grieving: finding the meaning of grief through the five stages of loss. 1st ed. New York: Simon and Schuster; 2014. p. 65-85.

16. Paterson BL. Meta-study of qualitative health research: A practical guide to metaanalysis and meta-synthesis. 3rd ed. USA: Sage; 2001. p. 72-80.

17. Karlıdağ R, Ünal S, Evereklioglu C, Sipahi B, Er H, Yoloğlu S. Stressful life events, anxiety, depression and coping mechanisms in patients with Behçet's disease. Journal of the European Academy of Dermatology and Venereology 2003; 17(6): 670-675.

18. Berg CA, Upchurch R. A developmentalcontextual model of couples coping with 
chronic illness across the adult life span. Psychological Bulletin 2007; 133(6): 920.

19. Rosland AM, Heisler M, Piette JD. The impact of family behaviors and communication patterns on chronic illness outcomes: a systematic review. Journal Of Behavioral Medicine 2012; 35(2), 221-239.

20. Stanton AL, Revenson TA, Tennen H. Health psychology: psychological adjustment to chronic disease. Annu. Rev. Psychol 2007; 58: 565-592.

21. Behçet H. Uber rezidivierende, aphthose, durch ein virus verursachte geshwure am munde, am auge und an den genitalien. Dermatologische Wochenschr 1937; 36: 1152-1157.

22. Demirhindi O, Yazıcı H, Binyıldız P, Dayığlu T, Tüzün Y, Altaç M. Silivri ve Fener köyü ve yöresinde Behçet hastalığ 1 sıklığı ve bu hastalığın toplum içinde taranmasında kullanılabilecek bir yöntem. Cerrahpaşa Tıp Fakültesi Dergisi 1981; 12: 509-504.

23. Özaltın F, Özen S. Ailevi Akdeniz Ateşi. Türkiye Tip Dergisi 2003; 10(2): 93-97.

24. Padeh S, Berkun Y. Familial Mediterranean fever. Current Opinion İn Rheumatology 2016; 28(5): 523-529.

25. Golics CJ, Basra MKA, Salek MS, Finlay AY. The impact of patients' chronic disease on family quality of life: an experience from 26 specialties. International Journal of General Medicine 2013; 6: 787.

26. Lahat A, Neuman S, Eliakim R, Ben-Horin S. Partners of patients with inflammatory bowel disease: how important is their support?. Clinical and Experimental Gastroenterology 2014; 7: 255.

27. Okyayuz ÜH. Kanser ve Behçet hastalarının ailelerinin duygudurum ve aile işlevleri açısından incelenmesi. Türk Psikoloji Dergisi 2004; 19(53): 87-99.

28. House JS, Landis KR, Umberson D. Social relationships and health. Science 1988; 241(4865): 540-545.

29. Troy, ML. The Impact IBD Can Have on Friends and Family. Health Union 2016;1: $1-10$.

30. Koçak M, Başar MM, Vahapoğlu G, Mert HÇ, Güngör Ş. The effect of Behçet's disease on sexual function and psychiatric status of premenopausal women. The Journal of Sexual Medicine 2009; 6(5): 1341-1348.

31. Hiz O, Ediz L, Gülcü E, Tekeoglu İ. Effects of Behçet's disease on sexual function and psychological status of male patients. The Journal of Sexual Medicine 2011; 8(5): 1426-1433. 